This item was submitted to Loughborough's Research Repository by the author.

Items in Figshare are protected by copyright, with all rights reserved, unless otherwise indicated.

\title{
Perceptions of status and TMO workgroup cooperation: implications for project governance
}

PLEASE CITE THE PUBLISHED VERSION

http://dx.doi.org/10.1080/01446193.2012.688137

PUBLISHER

Routledge (@ Taylor \& Francis)

VERSION

AM (Accepted Manuscript)

LICENCE

CC BY-NC-ND 4.0

\section{REPOSITORY RECORD}

Anvuur, Aaron M., Mohan M. Kumaraswamy, and Richard Fellows. 2019. "Perceptions of Status and TMO Workgroup Cooperation: Implications for Project Governance”. figshare. https://hdl.handle.net/2134/12344. 
This item was submitted to Loughborough's Institutional Repository (https://dspace.lboro.ac.uk/) by the author and is made available under the following Creative Commons Licence conditions.

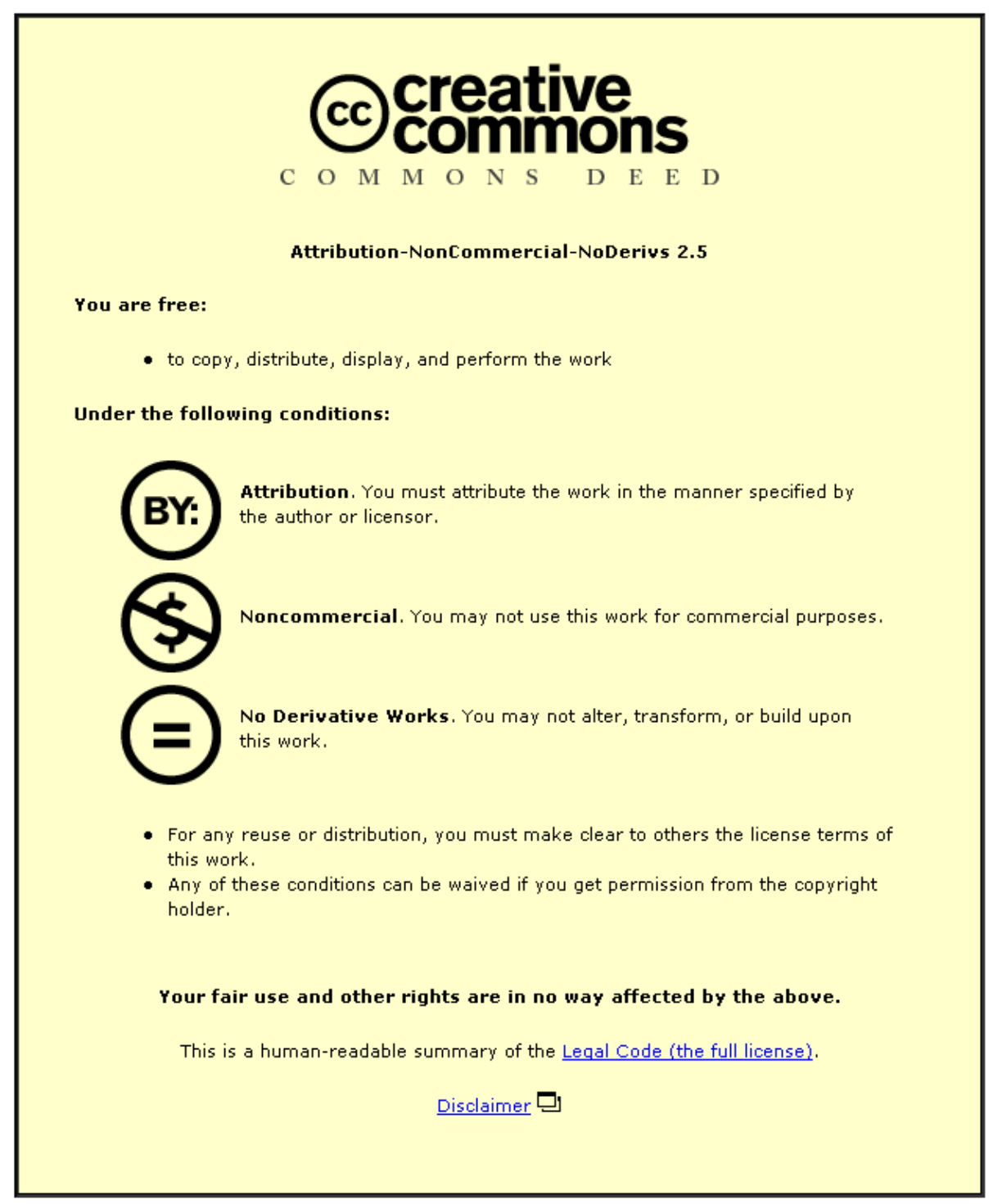

For the full text of this licence, please go to: http://creativecommons.org/licenses/by-nc-nd/2.5/ 


\title{
Perceptions of status and TMO workgroup cooperation:
}

\section{implications for project governance}

\author{
Aaron M. Anvuur, Mohan M. Kumaraswamy and Richard Fellows
}

Constr. Manage. Econ., 30(9), 719-737. http://dx.doi.org/10.1080/01446193.2012.688137

\begin{abstract}
Achieving and sustaining the cooperation of individuals with their temporary multiorganisation (TMO) workgroups is, arguably, one of the most enduring challenges facing the construction sector. A mediational model connecting pride and self-respect to each of four dimensions of cooperative behaviour - in-role, compliance, extra-role, and deference - is tested in a survey sample of 140 construction professionals in Hong Kong. Bootstrap tests of the indirect effect of pride on cooperative behaviour suggest that self-respect fully mediates the influences of pride on in-role behaviour and compliance behaviour, and partially mediates the influence of pride on extra-role behaviour. The results also suggest that pride has no effect on deference behaviour. While needing corroboration by future research, the findings suggest that viable strategies designed to foster pride and selfrespect could engender and sustain cooperation in construction TMO workgroups, and support ongoing efforts to reform construction. The bootstrapping procedures for testing intervening variable models are elaborated in the hope that this will encourage more process analysis research in construction.
\end{abstract}


Keywords: Cooperation, governance, pride, self-respect, temporary multi-organisation (TMO).

\section{Introduction}

The problems of the construction sector and their causes are generally well known and articulated. Courtney and Winch (2003) summarize these as being behavioural and organisational. The behavioural dimension underscores a chronic lack of cooperation between the temporary multi-organization (TMO) members involved in the design and delivery of construction projects and programmes (Phua, 2004), which also speaks for the organizational dimension as TMO member boundary spanning behaviours are crucial for the success of projects. Suggested solutions to these problems - renewal strategies include the use of alternative (to design-bid-build) procurement methods, new forms of contract and incentive mechanisms, supply chain management, as well as delivery modalities like partnering, alliancing and concurrent engineering. Generally, these renewal strategies have failed to create deep-seated improvements in attitudes, mindsets, behaviour, and project outcomes. Much of the blame for this has been placed on the design and marketing of, and research in, these renewal strategies, which have tended to emphasize their structural features (e.g. tools and techniques, critical success factors, hypothesized benefits) over the contextual and situational factors that underpin their effectiveness (e.g. Bresnen and Marshall, 2000). 
However, an analysis of the renewal strategies shows that, while they may have structural features that distinguish one from the other, they all use (or assume) the team approach as the primary means to execute their respective philosophies (Anvuur and Kumaraswamy, 2007). For clarity, this approach implies, at the very basic level, the existence of collectives consisting of differentiated and interdependent members (Pinto and Pinto, 1990; Katzenbach and Smith, 1993; Mohammed et al., 2010). In the context of TMOs, this entails collaboration between - joint creation by - cross-functional workgroup members (cf. Lawrence and Lorsch, 1967; Cherns and Bryant, 1984). Central to the team approach - and to the development of high-performance project teams - is a commitment-building process which, ultimately, leads to the establishment of a social contract that binds workgroup members to a common purpose and approach, and mutual accountability for workgroup performance (Katzenbach and Smith, 1993); this specific quality is, according to Katzenbach and Smith (1993), what differentiates teams from workgroups. The commitment building process usually involves the development of psychological mechanisms (or mental models), collectively referred to as emergent states, which mediate the influence of managerial interventions, workgroup processes and contextual factors on individual performance, workgroup performance and project outcomes (Mohammed et al., 2010). Reviews of teamwork and team development (e.g. Mathieu et al., 2008 ; Marrone, 2010) show an abundance of conceptual frameworks for and empirical evidence of the outcomes and antecedents of emergent state phenomena in the extant management literature. 
Similar conceptual frameworks have been developed in construction management research to explain the influences of emergent states, such as 'project chemistry' (Nicolini, 2002), group identification (Anvuur and Kumaraswamy, 2007), and team (psychological) empowerment (e.g. Rowlinson and Cheung, 2008). Similarly, there is a growing body of empirical research on the outcomes and predictors of various emergent states in construction TMOs. For example, organisational identification (Phua, 2004), empowerment (Liu et al., 2007; Tuuli and Rowlinson, 2009), and project affinity (Dainty, Bryman, et al., 2005) have all been demonstrated to influence individuals' efforts aimed at specific organisationally-relevant outcomes. However, no construction management research has examined the extent to which the psychological mechanisms based on status-relevant evaluations of group membership - pride and self-respect - influence the cooperation of individuals with their proximal TMO workgroups. This is a major shortcoming in the construction management literature, given that these status evaluations - along with organisational identification (cf. Mael and Ashforth, 1992) - have been demonstrated to be central to how individuals define their self-concepts - i.e. their social identity (e.g. Tyler and Blader, 2000, 2001).

The purpose of the present study is to address this shortcoming, by reporting the findings of empirical research, which investigates the influences of pride and self-respect on the cooperation of individuals with their proximal TMO workgroups. A secondary objective of this study is to make a research methods contribution by illustrating the stateof-the-art statistical procedures for testing mediational hypotheses using OLS regression. Such process analysis research that provides insight into the causal networks of constructs 
of interest is crucial for the further development of the construction management discipline (Winter et al., 2006), yet such research is rare. The majority of existing process analysis research studies use Baron and Kenny's (1986) 'three-steps and Sobel z' procedures (Lingard and Francis, 2005; Tuuli and Rowlinson, 2009; Lingard et al., 2010; Toor and Ofori, 2010). However, recent research emphasizes bootstrap confidence interval tests of the indirect effect and effect-size measures over null hypothesis significance tests and the Sobel z-test (Shrout and Bolger, 2002; MacKinnon et al., 2004). Only the study by Pesämaa et al. (2009) used these new procedures, specifically bootstrap tests of the indirect effect in structural equation modelling. By illustrating the new procedures in OLS regression, the statistical method of choice for most construction management researchers, it is hoped that established process analysis researchers will be encouraged to use the new and more robust procedures and that more construction management researchers will consider the possible intervening variable processes (mediation, moderated mediation, mediated moderation, and suppression) in their research designs. In the following sections, we discuss the relationships between the constructs of pride and self-respect and with the multi-dimensional cooperation construct. We then present the methods of research used and the results of our study. Finally, we discuss the findings and outline the implications for practice and for research.

\section{Cooperation of individuals with their TMO workgroups}

Cooperation is defined here as behaviour which promotes the goals of the workgroup or organisation that one belongs to (Katz, 1964; Tyler and Blader, 2000). From an organisation's or workgroup's perspective, such behaviours constitute performance (Katz, 
1964). The seminal work of Katz (1964; Katz and Kahn, 1978) set out what would later constitute the theoretical foundations of the motivational basis of organisational behaviour. Katz (1964) set out the key behaviours required for a high level of effectiveness of organisational functioning, the motivational patterns that underpin these behaviours, and the conditions for eliciting each motivational pattern. Katz and Kahn (1978) developed these ideas further through the framework of open systems theory. Open systems theory is notable for its adoption of an input-process-output approach with feedback loops, and for its refusal to accept existing structures as given. Open systems theory, and the work of Katz and Kahn (1978), pays homage to the seminal principle in Kurt Lewin's (cf. Gold, 1999) field theory: behaviour is a function of the interaction of person and environment (i.e. behaviour $=f$ person, environment]). An explication of the seminal work of Katz and Kahn is beyond the scope of this study, and has been elaborated in the context of construction elsewhere (see Anvuur and Kumaraswamy, 2008, 2011).

The seminal work of Katz and others closely building upon this (e.g. Smith et al., 1983; Williams and Anderson, 1991; Borman and Motowidlo, 1993; Motowidlo and Van Scotter, 1994; Tyler and Blader, 2000), suggests that role incumbents' cooperative behaviours vary on two dimensions: function of behaviour; and source of behaviour. The function of behaviour dimension distinguishes between behaviours that are production-function orientated and behaviours which aid coordination and restrain counterproductive workplace behaviour (Sackett, 2002). The source of behaviour dimension separates behaviours linked to the formal organisation (hence, obligatory) from behaviours linked to 
the informal organisation (hence, voluntary). The two dimensions result in four types of cooperative behaviour: extra-role; in-role; deference; and compliance.

Extra-role behaviour is voluntary production-function focused behaviour and includes volunteering to carry out extra task activities or helping peers with task-related problems not formally part of one's own job role. In-role behaviour is obligatory production-function focused behaviour, and involves role incumbents in carrying out tasks that are formally part of their job roles. Deference behaviour is voluntary rule-following behaviour that helps coordination and restrains counterproductive workplace behaviour, and includes willingly following organisational/workgroup rules or deferring to relevant authorities or best standards of appropriate behaviour where rules/norms do not exist. Compliance behaviour is calculative rule-following behaviour referenced to reinforcement mechanisms, and involves minimal observance of both task-specific and general organisational/workgroup rules (e.g. on health and safety) to avoid sanctions for rulebreaking. The distinctions between the four types of cooperative behaviour are, therefore, context-specific (Stone-Romero et al., 2009). However, the four types of behaviour are distinct yet related manifestations of the cooperation of individuals with their workgroups.

Given rapid changes in the organisation of work, towards flexible team-based structures which emphasize individual and team empowerment (Tuuli and Rowlinson, 2009), and the generality of role descriptions, role sending and role socialization (Katz and Kahn, 1978) which often expand role expectations beyond formal role prescriptions 
(Stone-Romero et al., 2009), role incumbents across organizations would inevitably be expected to routinely engage in all four types of cooperative behaviour. Numerous studies in industrial settings provide empirical evidence of the independent substantive effects of these four types of cooperative behaviour on the organisation effectiveness (e.g. Orr et al., 1989; Motowidlo and Van Scotter, 1994; Podsakoff et al., 1997).

Within the context of construction TMOs, cooperation has been the basis of project success (Barlow et al., 1997). Therefore, any research that advances our understanding of how (not) to foster cooperation in TMO settings is a valuable contribution to knowledge. Previous empirical construction management studies have provided some useful insights into this issue. For example, Phua (2004) found that individuals with high organisational identification, when compared to those with low organisational identification, exhibited more extra-role behaviour both within their organisations and in their TMO workgroups. Tuuli and Rowlinson (2009) conducted an empirical study into the performance consequences of empowerment both at the individual and team levels. Their findings show that empowerment climate has both positive direct and indirect effects, acting through both individual and team psychological empowerment, on in-role and extra-role behaviours. Likewise, Dainty et al. (2005a) found that construction operatives' emotional attachment to the cause of a cancer research facility, a phenomenon they termed "project affinity", led them to go the extra mile to support the production effort by freely engaging in extra-role behaviours. The current study complements this line of inquiry in construction management by investigating the utility of status evaluations as predictors of the cooperation of construction managers 
with their TMO workgroups. It also extends this line of inquiry by expanding the criterion domain of individual's cooperation to include in-role, extra-role, compliance, and deference behaviours. Below we briefly discuss the two group-related status evaluations that are the focus of the present study and then formulate specific hypotheses linking them to cooperation with the group.

\section{Organization-related status: pride and self-respect}

According to the group engagement model (Tyler and Blader, 2000, 2001, 2003; Blader and Tyler, 2009), individuals make two basic status evaluations with regard to the groups or organisations to which they belong, and these status evaluations shape their behavioural engagement with those groups or organisations. The two status evaluations are: an evaluation of the status of the group/organisation; and an evaluation of their own status within the group/organisation. Tyler and Blader (2000) used the term (group) "pride" to refer to the former and "respect" to refer to the latter. Empirical findings from surveys undertaken by Tyler and Blader (2000, 2001; Blader and Tyler, 2009) show that individuals who perceive high levels of pride and respect are likely to engage in cooperative behaviour, especially discretionary cooperation.

Other researchers have also investigated notions of pride, respect and/or other forms of group-related status. For example, from a conceptual standpoint, Khalil (2000) examined the utility of symbolic 'goods' (prestige, pride, self-respect, and dignity) and their distinction from substantive 'goods'. Roland and Foxx (2003) examined the notion of self-respect, highlighting its importance in understanding self-esteem and unique 
contribution to individual functioning. Tracy and Robins (2004) established the conceptual basis of pride as an adaptive self-conscious emotion that can encourage positive performance behaviours. Using case study and employee attitude surveys from over 2.5 million employees in 237 companies, Sirota et al. (2005) examined what motivates employees to go the extra mile for their organisations. Their findings highlight, among others ('fair-dealing', individual and team empowerment), the criticality of pride and respect. Using detailed case studies of companies in many industries, Katzenbach (2003) shows that while incentive plans are important for attracting and retaining talented employees, they are limiting in building emotional commitment. Instead, he argues, management can obtain superior and sustained performance from their employees by evoking pride and a sense of purpose in them. Using controlled experiments, Williams and DeSteno (2008) showed that proud individuals showed greater perseverance on effortful problem-solving tasks, and perceived high status in their groups and were most liked by group members (2009).

Pride, like most emergent states (Mohammed et al., 2010), has an adaptive and a maladaptive form. Authentic or achievement-orientated pride is a self-conscious emotion, which stems from forward-looking evaluation of the tenacity of action (Khalil, 2000; Tracy and Robins, 2004). Its maladaptive form, known as hubristic or egotistical pride, is where the experience of pride has no particular target - i.e. becomes an end in itself and disconnected from substantive achievement (Tracy and Robins, 2004). Hubristic pride is generally associated with poor social outcomes and is responsible for the generally negative view of the emotion in common parlance (Williams and DeSteno, 2008). Pride 
also comes in two varieties, depending on whether the referent is the group or the individual (Tracy and Robins, 2004; Sirota et al., 2005). Mascolo and Fischer (1995: 66) defined personal pride as an emotion "generated by appraisals that one is responsible for a socially valued outcome or for being a socially valued person". On the other hand, group pride implies identification with the accomplishments, track record and reputation of one's workgroup or organization, and the internalization of its causes and values (Tyler and Blader, 2003; Sirota et al., 2005). Previous research shows that the consequences of personal pride and group pride are analytically indistinguishable (Khalil, 2000; Tracy and Robins, 2004; Williams and DeSteno, 2008) and that the two tend to reinforce each other (Sirota et al., 2005). However, the present study focuses on authentic workgroup pride and subsequent uses of the term pride in this paper, unless otherwise qualified, shall refer to this specific form of the self-conscious emotion.

The notion of (self-) respect considered in the present paper is that which relates to purposive action (Khalil, 2000); it is 'respect for work' (Tyler and Blader, 2000). It is distinct from the Kantian notion of persons as ends in themselves and deserving of respect by self and others (Gregor, 1998) - i.e. 'respect for persons' - although the two notions of respect are united in ultimate purposes, as dimensions of human value (discussed later, also cf. Kane, 1998). Self-respect, like pride, also has its maladaptive (or distorted) form, which is generally to be differentiated based on the generality of the experiencewhether the experience is generalized and non-targeted or is specific (Khalil, 2000). This maladaptive form of self-respect, pomposity, is based on interpersonal comparisons of ability that are far removed from demonstrable performance (Khalil, 2000). The present 
paper focuses on the adaptive or authentic form of work-related self-respect. Hereafter, the term self-respect, unless otherwise qualified, shall refer to authentic work-related selfrespect.

We chose to examine self-respect, rather than respect, in the present study for three reasons: First, as respect is ultimately conferred upon a person by significant others, Tyler and Blader's (2000) conceptualization necessarily entails self-evaluations of other workgroup members' perceptions of one's worth or value as a group member. Indeed, on this basis Fuller et al. (2009) argued perceived organizational support (POS), "the extent to which the organization values their contributions and cares about their well-being" (Eisenberger et al., 1986: 501), to be consistent with Tyler and Blader's (2000) definition of respect. Self-respect, on the other hand, stems from behaviour that reflects one's estimated organizational ability (Khalil, 2000). Examining self-respect rather than respect, thus, avoids any potential confounding with POS, which is a heavily researched and important construct in its own right. Second, as it derives from intrapersonal evaluations, self-respect is the most individualistic form of organisation-related status (Khalil, 2000) and is perhaps less subjective in that regard. Finally, Roland and Foxx (2003) argue that self-respect is important in understanding self-esteem and uniquely contributes to an individual's functioning. Therefore, self-respect fits nicely within the group engagement model (Tyler and Blader, 2000, 2003).

In summary, pride and self-respect are occasioned by intrapersonal evaluations of action that confirm achievement and self-realisation respectively (Khalil, 2000; Williams 
and DeSteno, 2008). This sets them apart from related notions of admiration and prestige, which involve interpersonal (or inter-organisational) comparisons of ability (or capability) (Khalil, 2000). Pride and self-respect have also been shown to be conceptually distinct from self-efficacy and self-esteem (Tyler and Blader, 2000; Roland and Foxx, 2003; Williams and DeSteno, 2008). The two group-related status perceptions are also conceptually distinct constructs. Pride speaks to the categorical self and reflects a need to have a positive social identity, while self-respect speaks to the reputational self and reflects a need to have a positive personal identity (Tyler and Blader, 2003). Previous research suggests that pride and self-respect can be viable functional mechanisms for increasing the cooperation of individuals with their TMO workgroups.

While previous construction management studies have considered the performances consequences of other emergent state phenomena, such as organisational identification (Phua, 2004), empowerment (Liu et al., 2007; Tuuli and Rowlinson, 2009) and project affinity (Dainty, Bryman, et al., 2005), no study has considered the potential functional roles of the two status perceptions, pride and self-respect. The present study is, thus, unique in that sense. If positive effects were to be found for pride and self-respect, this would extend previous construction management research by adding to a growing list of temporal socio-psychological variables that are shown to predict value-enhancing behaviours in TMO workgroups and so help to temper the predominance of agentic models of performance in construction. 


\section{Study hypotheses}

Extant studies in conceptual (Khalil, 2000; Roland and Foxx, 2003), empirical (Tyler and Blader, 2001; Blader and Tyler, 2009) and experimental (e.g. Gaertner and Dovidio, 2000) contexts show that individuals who perceive high status within their organizations or workgroups are likely to engage in more cooperative behaviour and self-development activities. For example, Roland and Foxx (2003: 271) argue that self-respect is "the couch on which the cushion of self-esteem resides", and contributes to an individual's functioning by monitoring his or her behaviour and group contingencies and then motivates the individual to engage in behaviour that enhances the individual's development, approval from the group, and group effectiveness. Likewise, research shows that individuals' high in pride are likely to cooperate with their groups and to strive to acquire and demonstrate abilities. For example, pride has been shown to have a direct, positive effect on rule-following (compliance, deference) behaviour (Tyler and Blader, 2001) and production-function orientated (in-role, extra-role) behaviour (Katzenbach, 2003; Kahn, 2005; Sirota et al., 2005; Blader and Tyler, 2009). Therefore, previous research, as discussed above, suggests that pride and self-respect functional mechanisms for increasing the cooperation of individuals with their construction TMO workgroups.

Research on personal pride has shown that pride experiences facilitate increased effort on both individual (Williams and DeSteno, 2008) and group problem-solving (Williams and DeSteno, 2009) tasks. That line of research also demonstrates that personal pride enhances self-respect, social approval and acceptance from fellow group members or interactional partners (Roland and Foxx, 2003; Hardy and Van Vugt, 2006; Williams and 
DeSteno, 2009). If, as this line of literature as reviewed above suggests, the consequences of the two pride experiences (personal, group) are indistinguishable, we would expect (group) pride to have a significant, positive influence on self-respect. Therefore, our contention and main hypothesis is that not only are pride and self-respect functional mechanisms for increasing construction TMO workgroup members' cooperative behaviour, but also that the influence of pride on cooperation may be mediated by selfrespect. Figure 1 depicts this mediational model, which can be expressed in the following four sub-hypotheses:

$H_{1}$ : Self-respect mediates the relationship between pride and in-role behaviour.

$H_{2}$ : Self-respect mediates the relationship between pride and compliance behaviour.

$H_{3}$ : Self-respect mediates the relationship between pride and extra-role behaviour.

$H_{4}$ : Self-respect mediates the relationship between pride and deference behaviour.

Insert Figure 1 about here

\section{Method}

Sample and procedure

The questionnaire responses analysed were from 140 chartered built environment professional managers in Hong Kong. Average age of the participants was 44 years. Average total experience of the participants in construction was 20 years and average experience in current position was 7 years. All participants held managerial positions in 
the projects on which they reported, and all but three of them had at least a bachelor's degree. The sample consisted of 101 Chinese, 37 Caucasians and 2 participants with other ethnicities. The gender composition of the sample was 135 male and 5 female participants. The proportion of women managers in the sample (about 4\%) compares reasonably well with the total proportion of women employed in the Hong Kong construction sector (about 9\%, see Hong Kong Census and Statistics Department, 2011) and in the construction sectors of other developed countries such as Australia (about 13\%, see Francis, 2010) and the UK (about 10\%, see Worrall et al., 2010). The survey and data examination procedures, as described below, provide further methodological and empirical reasons to believe that the analysis sample was not biased.

Items for the present study were drawn from a larger questionnaire survey, which also included other attitudinal and value measures. The aim was to survey built environment professional managers in Hong Kong who have recent project experience. As the theoretical population was unknown, we defined a study population using the following purposive sampling procedure: first, we used the number of built environment professionals (engineers, project managers, quantity surveyors, and architects) who have chartered status (i.e. member or fellow) before 2006 as a proxy for the accessible population of built environment professional managers; second, using professional membership directories in Hong Kong, we identified the individuals who were accessible via full postal and/or email addresses and randomly selected 1100 of them who we invited to participate in the questionnaire survey; third, in order to identify and include only respondents with recent project experience, we included a screening/qualification 
question which asked each respondent whether or not he or she had participated in a project that was completed between 2002 and 2007 or was directly involved in an ongoing but relatively advanced construction project (yes/no). Respondents who answered 'yes' to the screening question (the 'eligibles') were asked to respond to the whole questionnaire. Those who answered 'no' (the 'non-eligibles') were directed, via a skip routine, to answer only demographic and social preference questions. The questionnaire items (save demographic and social preference items) were tailored to a project context by expressly asking each respondent to focus on his or her proximal TMO workgroup within one and the same specific project that he or she was recently involved in. After two mailings, interspersed with two reminders, a total of 153 'eligible' responses were received, representing a response rate of $18 \%$ or the higher rate of $20 \%$, when adjusting for the estimated number of 'non-eligibles' in the sampling frame. This response rate compares reasonably well with those reported in many similar previous construction management studies (e.g. Phua, 2004).

This initial dataset was examined for (item and unit) non-response bias, violations of multivariate normality, and social desirability bias using the normal procedures and techniques for data examination (cf. Hair et al., 2010), including: missing value analysis; testing for systematic differences in 14 demographic and social preference variables between early respondents and later respondents (as surrogates for non-respondents, cf. Armstrong and Overton, 1977) and between 'eligible' and 'non-eligible' respondents; examination of advanced diagnostic and influence statistics; and testing for social desirability bias using Strahan and Gerbasi's (1972) 10-item short version of the Crowne 
and Marlowe (1960) 33-item social desirability scale. These tests resulted in 13 cases being discarded and confirmed the suitability of the remaining sample of 140 cases for the subsequent analyses.

\section{Measures}

Scale items in this study were adapted from previously validated scales (see below) and were all phrased as questions using a 5-point Likert scale. Likert scales have been shown to provide an efficient means of capturing a wide range of variance in self-reported attitudes and behaviours, and have better psychometric properties (reliability and validity) when the response categories are between four and seven (Lozano et al., 2008). For the present study, a 5-point response format was used as it includes a central point and because it was considered that a 7-point scale might be too taxing of the discriminative capacity of potential respondents for whom English is a second language. The dimensionalities of the constructs were confirmed in this study by exploratory principal components factor analysis with Varimax rotation. Items that cross-loaded, had absolute loadings less than .50 or measures of sampling adequacy less than .50 were candidates for deletion. Retained scale items were then examined for their internal consistency. The final scales demonstrated strong item-total correlations (min. $r>.50$ ) and internal consistencies (Cronbach's alpha > .70). See scale items in the Appendix.

\section{Dependent variables: cooperation dimensions}

Items measuring individuals' in-role, extra-role, compliance, and deference behaviours were adapted from previously validated scales in studies building closely on the seminal work of Katz (e.g. Smith et al., 1983; Williams and Anderson, 1991; Borman and 
Motowidlo, 1993; Tyler and Blader, 2001), and were validated in a previous construction management study (see Anvuur and Kumaraswamy, 2011). All the scales for the cooperation dimensions utilised a 5-point response format ranging from $1=$ never to $5=$ very often.

In-role. This was investigated using five items, which assessed role incumbents' performance of job tasks that were formally required as part of their work roles (e.g. “I fulfil the responsibilities specified in my job description"). Cronbach's alpha was .89 for this scale.

Extra-role. This was assessed with four items which tapped role incumbents' performance behaviours that involved them in volunteering to carry out extra-task activities or helping peers solve task-related problems not formally part of their own work role (e.g. "I volunteer to do things that are not required in order to help my workgroup"). Cronbach's alpha was .78 for this scale.

Compliance. This was measured with three items which assessed the extent to which role incumbents followed work-related and supervisor rules because they perceived them to be obligatory (e.g. "I comply with work related rules and regulations"). Cronbach's alpha was .88 for this scale.

Deference. This was assessed with three items which tapped role incumbents' performance behaviours that involved them in voluntarily following work rules and deferring to relevant authorities or best standards of appropriate behaviour where rules/norms did not exist (e.g. "I willingly follow my project organisation's policies"). Cronbach's alpha was .83 for this scale. 
Independent variables

Self-respect. This was measured with the four-item membership sub-scale of Luhtanen and Crocker's (1992) four-dimensional collective self-esteem scale (e.g. "I am an important member of my workgroup"). Scale anchors ranged from 1 = strongly disagree to 5 = strongly agree. Membership collective self-esteem and its corresponding scale items are consistent with the definition of self-respect in the present study (i.e. as intrapersonal evaluations of action that confirm self-realisation). According to Luhtanen and Crocker (1992), the membership esteem sub-scale is the most individualistic aspect of the collective self-esteem scale, and measures role incumbents' self-evaluations of how valuable or worthy they are as members of their workgroups. Cronbach's alpha was .73 for this scale.

Pride. Pride in affiliation was measured with five items adapted from O’Reilly and Chatman's (1986) pride-via identification, and pride-via internalisation scales (e.g. “I 'talk up' where I work to my friends as a good place to work"). The five items assessed how proud role incumbents were to be part of their work settings, identifying with or internalising their project organisations' (and workgroups'), causes, values and accomplishments. Cronbach's alpha was .85 for this scale.

\section{Control variables}

We also controlled for each respondent's age, gender, educational attainment, ethnicity, and satisfaction with their pay. Previous studies (e.g. Smith et al., 1983; Phua, 2004; Blader and Tyler, 2009) have found or argued these variables to be associated with one or 
more of the attitudinal and behavioural variables in the present study. Age, gender, educational attainment, and ethnicity were coded as dummy variables: age, $0 \leq 40$ years and $1>40$ years; gender, $0=$ male and $1=$ female; educational attainment, $0=$ undergraduate degree or below and 1 = postgraduate education; ethnicity, $0=$ nonChinese and 1 = Chinese. Pay satisfaction was measured with two items: "Overall, I receive excellent pay and benefits where I work"; and "I am satisfied with my pay". Cronbach's alpha was .89 .

\section{Data analysis procedure}

Procedure for determining the existence of a mediation process

Application of the Baron and Kenny (1986) mediation procedure would require the estimation of the following three regression models:

$$
\begin{gathered}
D V=i_{1}+c I V+e_{1} \\
M E D=i_{2}+a I V+e_{2} \\
D V=i_{3}+c^{\prime} I V+b M E D+e_{3}
\end{gathered}
$$

Where, $i_{j}$ and $e_{j}$ are the intercept and error terms respectively. Note that, for convenience, no distinction is made in the present paper between population parameters (e.g. a) and their corresponding sample estimates (e.g. â).

In Equation 1, the total effect, $c$, of pride (the independent variable; IV) on cooperation (the dependent variable; $D V$ ) is obtained by regressing cooperation on pride. Figure 1 shows how this total effect of pride can be apportioned into its indirect effect on cooperation through self-respect (the mediator variable; MED) and its direct effect on 
cooperation (path $c^{\prime}$ ). Path $a$ represents the effect of pride on self-respect and is obtained by regressing self-respect on pride as in Equation 2. Path $b$, the effect of self-respect on cooperation while controlling for the effect $\left(c^{\prime}\right)$ of pride, is obtained by regressing cooperation on both self-respect and pride as in Equation 3 above. The indirect effect of pride on cooperation through self-respect can then be quantified as the product of the unstandardised regression weights $a$ and $b$ (i.e. $a b$ ). Note that the above identities can be linked by the equation $c=a b+c^{\prime}$ but only (Preacher and Hayes, 2008): (1) in multiple regression and structural equation models where $M E D$ and $D V$ are continuous variables, (2) when there are no missing data, and (3) when the same covariates (control variables) are in the equation. Statistically significant effects for paths $c, a$ and $b$ (as expressed in eqns. 1, 2 and 3 above) and a significant Sobel's z-test constitute the popular Baron and Kenny (1986) "three tests + Sobel" steps for testing mediation. The Sobel z-test tests the null hypothesis that the indirect effect $a b=0$ (Sobel's z $=a b / S E_{\text {sobel }} ;$ where, $S E_{\text {sobel }}=$ $\sqrt{a^{2} S E_{b}^{2}+b^{2} S E_{a}^{2}}$ and $S E_{i}$ is the standard error for identity $\left.i\right)$. If the absolute value of the z score is larger than 1.96, it is statistically significant at the .05 level (Baron and Kenny, 1986).

However, subsequent research has indicated some necessary revisions to the Baron and Kenny (1986) mediation procedure. Firstly, the Baron and Kenny steps have been restated in terms of zero and nonzero coefficients to reflect a general trend in the psychology and social science disciplines to stress the importance of confidence intervals (Cls) over null hypothesis significance tests (Shrout and Bolger, 2002); if the $\mathrm{Cl}$ of an estimate does not include zero, then the effect in question is considered to be significant. 
Secondly, the requirement that there should be "an effect to be mediated", that is, a significant total effect, $c$ (step/eqn. 1 above), is now considered to be unnecessary (Zhao et al., 2010). This is because in the case of distal mediation processes and when suppression (explained later in the text) is hypothesized or suspected, step 1 is not likely to be met (Shrout and Bolger, 2002; MacKinnon et al., 2004). Therefore, the definitive test of mediation is a significant indirect effect $a b$; thus, only (steps) eqns. 2 and 3 above are required.

Researchers have also criticised the assumption of normality of the sampling distribution of the product $(a b)$ and the Sobel's z, which hold only for very large sample sizes (MacKinnon et al., 2004). The assumption of normality makes the Sobel z-test very conservative; that is, the $95 \% \mathrm{Cl}$ for the indirect effect $\left(a b \pm 1.96 S E_{\text {sobel }}\right)$ will include zero more often than would the $95 \% \mathrm{Cl}$ created from the theoretical sampling distribution of $a b$ (Shrout and Bolger, 2002). Bootstrap tests of the indirect effect are considered to be more powerful than the Sobel z-test and do not impose an assumption of normality (Cheung and Lau, 2008). Bootstrapping involves sampling with replacement (thousands of times) from the original data set and estimating the indirect effect $(a b)$ in each resampled data set (Shrout and Bolger, 2002; MacKinnon et al., 2004). This way, the empirical distribution of $a b$ is used to approximate its theoretical distribution and to generate the $\mathrm{Cl}$.

There are several methods by which to construct bootstrap Cls, a discussion of which is beyond the scope of the present study. For a review of the available methods, the 
interested reader should see, for example, MacKinnon et al. (2004) and Cheung and Lau (2008). Based on simulation studies, MacKinnon et al. (2004) concluded that the biascorrected and accelerated bootstrap $(\mathrm{BCa})$ procedure is the single best method overall in terms of closeness to nominal Type I error rates and statistical power. Preacher and Hayes (2008) recommend 1000 bootstrap resamples for preliminary analyses and 5000 for final reporting, and have developed SPSS macros for generating bootstrap Cls for the indirect effect in OLS regression designs. Shrout and Bolger (2002) and Cheung and Lau (2008) describe the procedure for and provide practical recommendations on generating bootstrap Cls of the indirect effect in structural equation models using popular software packages like AMOS, LISREL and EQS.

\section{Procedure for determining the type mediation process}

While the definitive test of mediation is a significant indirect effect $a b$, the magnitudes, directionalities and $p$-values of the $a, b, c^{\prime}$ and $c$ paths, hence Baron and Kenny's (1986) three equations above, are important in determining the exact type of intervening variable process (mediation, nonmediation or suppression) that is indicated, and may also be instructive for theory building (Shrout and Bolger, 2002; Cheung and Lau, 2008; Zhao et al., 2010):

1. If neither a direct effect $\left(c^{\prime}\right)$ nor indirect effect $(a b)$ exists, the situation is no-effect nonmediation.

2. If a direct effect $\left(c^{\prime}\right)$ exists but there is no indirect effect $(a b)$, there is direct-only nonmediation. 
3. If a direct effect $\left(c^{\prime}\right)$ and indirect effect $(a b)$ both exist and are in the same direction, then there is complementary mediation (or "partial mediation").

4. If an indirect effect $(a b)$ exists but there is no direct effect $\left(c^{\prime}\right)$, then the mediation process is indirect-only mediation (or "full mediation").

5. If the indirect effect $(a b)$ and direct effect $\left(c^{\prime}\right)$ both exist but are in opposite directions, there is suppression.

In the special case where the proposed independent and mediator variables have significant zero-order bivariate associations of roughly the same magnitude and direction with the dependent variable, a redundancy situation results (Tzelgov and Henik, 1991). Shrout and Bolger (2002) have also shown that $50 \%$ of the time when a full mediation process exists in the population (i.e. $c^{\prime}=0$ ), the sample estimates of the direct effect, although nonsignificant, can be expected to be in an opposite direction to the indirect effect $(a b)$ - this spurious situation they said is an artifactual result of sampling fluctuations.

One of the main advantages of the above guidelines over the Baron and Kenny steps is the ability to identify and test suppression situations. Research distinguishes between three types of suppression situations namely classical suppression, cooperative suppression, and net suppression (Paulhus et al., 2004). Previously only recognised for their ability to enhance the predictive validities of one or more predictors (Tzelgov and Henik, 1991), suppression situations (specifically, cooperative and net suppression situations) are now also considered to have theoretical import, including indicating the 
possibility of an omitted mediator (Shrout and Bolger, 2002; Paulhus et al., 2004). A detailed discussion of the three types of suppression situations and their theoretical implications is beyond the scope of the present study. The interested reader should refer to Tzelgov and Henik (1991) and Paulhus et al. (2004). Also, a confirmed case of complementary (or partial) mediation is often considered to be indicative of an omitted mediator of the same sign as the indirect effect (Shrout and Bolger, 2002; Zhao et al., 2010).

The present study

In the present study, we used the $\mathrm{BC}$ a procedure with 5000 resamples and Preacher and Hayes' (2008) SPSS OLS regression macro for multiple mediation to generate $95 \% \mathrm{Cls}$ for the indirect effects $(a b)$ of pride on in-role, compliance, extra-role and deference behaviours acting through self-respect. If the $95 \% \mathrm{Cls}$ do not include zero, then the indirect effects would be considered to be significant. The Preacher and Hayes' macro also provides estimates of the $a, b, c$ and $c^{\prime}$ paths (as in Equations 1, 2 and 3 and Figure 1 above). Ethnicity, age, gender, educational attainment and pay satisfaction were included as covariates in each regression model estimated. Table 1 shows descriptive statistics and correlations among the study variables. Table 2 shows the results of the regression analyses.

Insert Table 1 about here 


\section{Results}

As the results in Table 1 show, of the control variables (covariates), only gender was not significantly associated with any of the variables of interest in the present study. Ethnicity was significantly correlated with compliance $(r=0.20, p=.016)$ and deference $(r=0.17, p$ $=.041)$ behaviours. Age was significantly correlated with pay satisfaction $(r=0.23, p=$ $.006)$ and self-respect $(r=0.18, p=.034)$, while education was significantly correlated with only pride $(r=0.18, p=.035)$. Finally, pay satisfaction was significantly correlated with pride $(r=0.45, p=.000)$, self-respect $(r=0.17, p=.047)$ and extra-role behaviour $(r=0.20$, $p=.021)$. Thus, ethnicity and pay satisfaction were the only control variables that were significantly associated with cooperation. As can be seen from the results in Table 1, a pattern of positive and statistically significant intercorrelations among pride, self-respect and all four cooperation dimensions $(r \geq 0.19, p<.03)$ was observed, thus providing preliminary support for our hypotheses.

Insert Table 2 about here

The results of the regression analyses, presented in Table 2, provided substantive support for our hypotheses. The directions of the $a$ and $b$ paths were consistent with the interpretation that greater pride in affiliation leads to greater self-respect, which in turn leads to greater in-role, compliance, extra-role, and deference behaviours. An examination of the specific indirect effects of pride acting through self-respect indicated 
significant effects for the pride $\rightarrow$ in-role, pride $\rightarrow$ compliance, and pride $\rightarrow$ extra-role relationships but not the pride $\rightarrow$ deference relationship, since the $\mathrm{Cl}$ for the indirect effect $(.0006, .1655)$ included zero. Referring to the procedures, as discussed above, for determining the type of intervening variable process there is in process analysis research, we concluded the following about our study hypotheses:

- Hypothesis $H_{1}$ is supported. Self-respect mediates the relationship between pride and in-role behaviour. Based on guidelines discussed earlier, the mediation process can be described as indirect-only mediation (or full mediation).

- Hypothesis $\mathrm{H}_{2}$ is supported. Self-respect mediates the relationship between pride and compliance behaviour. Based on guidelines discussed earlier, the mediation process can be described as indirect-only mediation (or full mediation).

- Hypothesis $\mathrm{H}_{3}$ is supported. Self-respect mediates the relationship between pride and extra-role behaviour. Based on guidelines discussed earlier, the mediation process can be described as complementary mediation (or partial mediation).

- Hypothesis $\mathrm{H}_{4}$ is not supported. Self-respect does not mediate the relationship between pride and deference behaviour. Based on guidelines discussed earlier, the intervening variable process can be described as no-effect nonmediation.

\section{Discussion}

The primary purpose of this research was to investigate the adaptive consequences of two organisation-related mechanisms of human status - pride and self-respect - by deriving and testing predictions linking these emotions to individuals' in-role, compliance, extrarole, and deference behaviours in their proximal TMO workgroups. Specifically, the 
findings show that individuals high in pride tend to view themselves as being selfrespecting which, in turn, leads them to exhibit more in-role, compliance, extra-role, and deference behaviours. The findings also show that self-respect fully mediates the influence of pride on in-role and compliance behaviours and partially mediates the influence of pride on extra-role behaviour. These findings are generally consistent with prior research, which demonstrates the adaptive social and organisational effectiveness consequences of pride and self-respect; for example, Sirota et al. (2005) who found that not only did pride improve the productivity, quality and financial outcomes of the companies they studied, pride also benefited from these outcomes so as to create a virtuous cycle. Similarly, Katzenbach (2003) found that pride is a powerful motivating force with the potential to become an institutional capability that builds organisational responsiveness and generates strategic advantage and, through self-realisation, occasions feelings of self-respect in organisational members at the front-line. The findings are also quite consistent with Williams and DeSteno's (2009) finding that personal pride enhances self-respect and social approval from interaction partners.

In particular, our findings reinforce the findings of Tyler and Blader $(2000,2001)$ in demonstrating that pride and respect (for self) are functional social mechanisms for increasing the cooperation of individuals with their proximal TMO workgroups. However, our findings also differ from those of Tyler and Blader (2001) in important respects. Tyler and Blader (2001) found that pride predicted only compliance and deference behaviour while respect predicted only in-role and extra-role behaviour. In explaining this differential pattern of influence, Tyler and Blader (2001: 222) argued that pride predicts "aspects of 
behaviour that are group-level and deal with people's relationship to the group and group norms and values" and respect, "those aspects of behaviour the flow from individual level concerns". In contrast, the present study found that self-respect fully mediates the influence of pride on in-role and compliance behaviour, and partially mediates the influence of pride on extra-role. This finding may be further evidence that self-respect is conceptually distinct from (if related to) respect (cf. Bird, 2010); a distinction which, according to Bird (2010), derives from the principle of personal responsibility ('personal causality') that underpins the notion of self-respect. In this sense, the present study extends the group engagement model by demonstrating that - besides respect of others self-respect is also a viable functional mechanism for increasing the cooperation of individuals with their TMO workgroups.

Also in contrast to the finding of Tyler and Blader (2001), and disconfirming our mediational hypothesis, the present study found that pride had neither a direct nor indirect influence (through self-respect) on deference behaviour; this is despite a pattern of positive and significant $a$ and $b$ paths, as observed in Table 2 . While a finding of noeffect can occur despite a pattern of positive and significant $a$ and $b$ paths (Zhao et $a l$., 2010), further research is required to better understand any relationship of pride and selfrespect with deference. On a speculative note, it is possible that after partialling out the influence of ethnicity on rule-following (discussed in next paragraph below), there was not enough variance remaining in the pride and self-respect measures to predict deference behaviour. Overall, however, the findings of the present study provide strong evidence of 
the adaptive functional roles of pride and self-respect in promoting individuals' cooperation with their construction TMO workgroups.

As mentioned above, ethnicity had a significant, positive influence on both compliance $(\beta=0.30, p=.008)$ and deference behaviour $(\beta=0.26, p=.032)$ in the present study. This finding suggests that Chinese respondents $(N=101)$ in the sample were more likely than their non-Chinese counterparts $(N=39)$ to comply with or defer to work rules and regulations. This finding, although unhypothesized, is significant given what we know from previous research about Chinese culture. Generally, Chinese are considered as collectivists, who display high levels of power-distance and tend towards self-restraint and rule compliance, even self-deprecation (cf. Hofstede et al., 2010). This finding of a positive relationship between Chinese ethnicity and rule-following behaviour is, thus, consistent with and reinforces previous research and complies with behaviour noted in Chinese history.

A secondary objective of the present study - to illustrate the state-of-the-art bootstrapping procedures for testing mediation and the indirect effect, as well as guidelines for 'diagnosing' the type of intervening variable process indicated - has been achieved. Construction management researchers can usefully apply the techniques and procedures illustrated in this paper to increase their chances of identifying intervening variable processes, and ultimately to advance our understanding of the 'causal' networks associated with the numerous classificatory systems of critical success factors in 
construction. Such process analysis research is crucial for the further development of the discipline (Winter et al., 2006).

\section{Practical Implications}

The findings of this study have important practical implications for project governance. First, pride and self-respect can be fit-for-purpose (i.e. less accidental, more consistent and sustainable) strategies for increasing the engagement of project actors with their TMO workgroups. TMO workgroup members are boundary spanners (Cherns and Bryant, 1984) whose decisions and actions have profound impacts on project outcomes (Dainty, Cheng, et al., 2005). Yet, project actors' self-concepts are often closely linked to their professional or functional role affiliations, which has been shown to result in limited cooperation in construction projects (e.g. Ankrah and Langford, 2005). A major challenge confronting project managers, therefore, is how to motivate project actors to cooperate with their TMO workgroups in order to achieve project objectives. The findings of this study provide good promise for a solution to this problem. Given their strong professional and functional role orientations and the fact that pride and self-respect derive from selfevaluation of purposive action, construction TMO workgroup members are especially prone to experiencing pride and self-respect. As pride and self-respect experiences are only temporary - due to their being associated with specific work-related accomplishments - the tendency is for proud and self-respecting TMO workgroup members to strive for ongoing individual and collective achievements that favour consistent performance outcomes; these continuous learning processes have the potential to create virtuous cycles (Sirota et al., 2005). Starting conditions are therefore very important. These determine whether the cycles will be virtuous, where high levels of 
pride and self-respect lead to better performance and therefore higher levels of pride and self-respect, or, vicious, where low levels of pride and self-respect lead to poor performance and therefore lower levels of pride and self-respect. In this sense, our findings provide support for team-building sessions and other 'partnering' initiatives emphasizing the celebration of both symbolic and substantive joint successes, and the usual exhortations to TMO workgroup members in these contexts to take pride in their achievements (cf. Anvuur and Kumaraswamy, 2007).

Second, pride and self-respect are central to group identification processes and so may provide viable avenues for reducing the bias, stereotyping and adversarialism that have been found to be associated with the strong professional/functional role specialisms and orientations in construction. Previous research shows that individuals who are prone to experience pride or self-respect readily identify with their workgroups (Tyler and Blader, 2001; Sirota et al., 2005), and that group identification leads to discretionary cooperative behaviour (Mael and Ashforth, 1992; Phua, 2004). Therefore, previous research suggests that pride and self-respect are also functional mechanisms for increasing the identification of TMO project actors with their proximal workgroups and thus for reducing the potential for adversarial relationships. Given the many circles of inclusion in and the transient nature of construction projects (Fellows, 2006), an individual's identification with his or her TMO workgroup would necessarily be superordinate in nature - an inclusive categorization of the aggregate (Gaertner and Dovidio, 2000) - and temporary. Similarly, any pride climate or self-respect climate developed in construction project settings would be temporary (Fellows, 2006). However, 
at the firm and institutional (sector) levels, cooperation strategies based on pride and selfrespect can take on cultural significance (Tyler and Blader, 2000; Sirota et al., 2005). Thus, our findings provide information pertinent to ongoing efforts to transform the 'culture' of construction (Anvuur and Kumaraswamy, 2007); efforts which we believe are more importantly concerned with understanding and shaping the aspects of governance structures and processes that create and sustain the attitudes and values that encourage cooperation on construction projects (Kumaraswamy et al., 2005; Fellows, 2006). As Pettigrew (1998) notes, behavioural change is the foundation for attitudinal change; the dissonance between new behaviour and old attitudes (prejudices, biases, and mindsets) is often resolved by revising one's attitudes.

Third, our findings on the adaptive functional roles of pride and self-respect may be instructive for construction sector efforts to promote the dignity, intrinsic worth and wellbeing of the workforce. Consider, for example, the Respect for People (2004) initiative in the UK, the core principles of which are also reflected in the Construction Industry Review Committee report (CIRC, 2001). When stripped of all the politics, cynicism, and power struggles associated with its introduction (see Ness, 2010), the two Respect for People foci of 'people as assets' and 'people as ends in themselves' are not inherently conflicting or contradictory. Instead, they entail two dimensions of human value (Kane, 1998): the former is consistent with economic or instrumental value; and the latter, with moral or ethical value. The (moral/ethical) issues that Respect for People, along with the general partnering ethos and legislation, has highlighted and campaigned for - for example, health, safety, well-being, and diversity/inclusivity, as aspects of corporate social 
responsibility - are all now recognised as important dimensions of organisational (Liu et al., 2011) and project management (Anvuur et al., 2011) effectiveness. This is significant for two reasons. First, people develop value-expressive attitudes and behaviours in order to project and uphold their moral values in the groups/organisations to which they belong (Kane, 1998). Second, and more pertinent, pride and self-respect stem from intrapersonal evaluations - i.e. are by-products - of forward-looking action in pursuit of instrumental value. Therefore, to the extent that these moral value criteria are reflected in organisational and project goals, pride and self-respect constitute viable mechanisms for achieving not only cooperation in projects, but also through identification processes and replication, the much desired changes in mindsets and attitudes in the construction sector as a whole.

Finally, previous research suggests that pride and (self-) respect based strategies for employee engagement - in contrast to agentic models - are cost effective. Because they derive from intrapersonal evaluations of substantive action, pride and self-respect are only subject to indirect managerial interventions - through the design and management of the social environment (milieu) of projects. Previous research suggests that governance systems and action that promote - through both policy articulation and behavioural enactment - ethical standards, justice (or fairness), employee opportunities (for upskilling; of challenging work; for performance feedback), concern for employee well-being, and participative safety, provide the favourable cues relevant to the status evaluations central to the experience of pride and (self-) respect (Blader and Tyler, 2009). In summary, therefore, the present research suggests that pride and self-respect 
mechanisms ought to be given serious consideration by project managers in decisionmaking about the governance of projects.

\section{Limitations and future research}

There are important limitations to the research reported in this paper, which we now discuss. First, questions about the generalisability of the findings arise naturally due to the characteristics of the study sample. We have addressed this concern in part by including statistical controls for the effects of ethnicity, age, gender, educational attainment, and pay satisfaction on in-role, extra-role, compliance, and deference behaviour. Except for the significant, positive effects of ethnicity on compliance and deference behaviour, there were no significant effects for the other control variables. However, further research is required to corroborate the findings reported in this paper. As noted earlier, future research is also required to improve our understanding of the pride-deference relationship, in particular to confirm whether the finding of no-effect for pride is despite or because of the strong influence of Chinese ethnicity on rule-following observed in the present study and consistent with behaviour as noted in Chinese history.

Second, the finding of a direct effect of pride on extra-role behaviour $(\theta=0.17, p<$ .05), that is, over and beyond its indirect effect through self-respect, may be indicative of an 'omitted' mediator or just an artefact of errors in the indicant measures of self-respect used in this study (Zhao et al., 2010). In the former scenario, future research using SEM techniques, which have the capability to model measurement error (Cheung and Lau, 2008), would be required. In the latter scenario, future research may usefully look for an 'omitted' mediator of the same (positive) sign as the sign of the indirect effect $a b$. On a 
speculative note, the 'omitted' mediator might be organisational identification, which, as discussed above (see practical implications section), has been shown to mediate the influences of pride and self-respect on cooperation, especially discretionary cooperative behaviour. In either case, future research is needed to further our understanding.

Third, the use of self-report data in the present study may be a concern because of the potential for effect size inflation due to common method bias. This concern has been tempered in the present study by following all the procedural remedies for controlling common method bias, including the disconfirming statistical evidence of its existence in the dataset (see method section). Nonetheless, future research that utilises more objective measures such as supervisor ratings, and statistical techniques (e.g. MultitraitMultimethod Matrix; MTMM) that are capable of modelling the effects of common method bias is particularly encouraged.

Finally, in addition to the need for direct and conceptual replications as discussed above, a useful extension to the present paper would be to investigate the cooperation consequences of pride and self-respect at the workgroup or team level. Nevertheless, the findings of the present study provide important insights into how to enhance the engagement of project actors with their TMO workgroups.

\section{Conclusion}

The purpose of this study was to investigate the influences of pride and self-respect on the cooperation of individuals with their proximal TMO workgroups. A mediational 
hypothesis connecting pride and self-respect, acting as a mediator, to in-role, compliance, extra-role, and deference behaviour was empirically tested using a sample of 140 built environment professional managers in Hong Kong. An elaborated account of the bootstrap procedure used in testing the mediational hypothesis in OLS regression was provided in the hope this would encourage more process analysis type research studies in construction management. The findings show that self-respect fully mediates the influence of pride on in-role, and compliance behaviour, and partially mediates the influence of pride on extra-role behaviour. Pride neither has a direct nor indirect effect on deference behaviour.

While the findings provide generally support the study hypotheses and are consistent with previous research, they do not prove causality. The finding that pride has no effect on compliance and deference in this study may be because most of the variance in pride was partialled out by ethnicity but it was not possible to confirm this in the present study. Therefore, future research is required to corroborate the findings reported in this study, and to clarify the precise influence of pride on compliance and deference.

However, the findings of this study, if confirmed by future research, make a contribution to knowledge by adding pride and self-respect to the growing lexicon of adaptive emergent states that are shown to mediate managerial interventions directed at enhancing value creation in construction TMOs. In practical terms, the findings highlight the viability of pride and self-respect based strategies for increasing individuals' cooperation with their TMO workgroups. Because they have been shown by previous 
research to lead to an inclusive categorisation of the aggregate, experiences of pride and self-respect may be effective in reducing the bias, stereotyping and adversarialism that is so often associated with construction TMO settings. However, because they are emergent states, pride and self-respect can only be influenced indirectly; by enhancing the salience of the cues which lead to the positive self-evaluations of purposive action pertinent to the experiences of pride and self-respect. Given this, project managers may wish to seek to promote professionalism on their projects but within an inclusive context that emphasizes complementarity of the specialisms, contractual solidarity, and the celebration of both symbolic and substantive joint successes.

\section{References}

Ankrah, N.A. and Langford, D.A. (2005) Architects and contractors: a comparative study of organizational cultures. Constr. Manage. Econ., 23(6), 595-607.

Anvuur, A.M. and Kumaraswamy, M.M. (2007) Conceptual model of partnering and alliancing. J. Constr. Eng. Manage., 133(3), 225-234.

Anvuur, A.M. and Kumaraswamy, M.M. (2008) Better collaboration through cooperation. In: Smyth, H. and Pryke, S. (Eds.), Collaborative relationships in construction: developing frameworks and networks, pp. 107-128. Oxford: Wiley-Blackwell.

Anvuur, A.M. and Kumaraswamy, M.M. (2011) Measurement and antecedents of cooperation in construction. J. Constr. Eng. Manage., 10.1061/(ASCE)CO.19437862.0000498(Oct. 18, 2011). 
Anvuur, A.M., Kumaraswamy, M.M. and Mahesh, G. (2011) Building "relationally integrated value networks" (RIVANS). Eng. Const. Arch. Manage., 18(1), 102-120.

Armstrong, J.S. and Overton, T.S. (1977) Estimating nonresponse bias in mail surveys. J. Mark. Res., 14(3), 396-402.

Barlow, J., Cohen, M., Jashapara, A. and Simpson, Y. (1997) Towards positive partnering. Bristol: The Policy Press.

Baron, R.M. and Kenny, D.A. (1986) The moderator-mediator variable distinction in social psychological research: conceptual, strategic, and statistical considerations. J. Pers. Soc. Psychol., 51(6), 1173-1182.

Bird, C. (2010) Self-respect and the respect of others. Eur. J. Philos., 18(1), 17-40.

Blader, S.L. and Tyler, T.R. (2009) Testing and extending the Group Engagement Model: linkages between social identity, procedural justice, economic outcomes and extrarole behavior. J. Appl. Psychol., 94(2), 445-464.

Borman, W.C. and Motowidlo, S.J. (1993) Expanding the criterion domain to include elements of contextual performance. In: Schmitt, N. and Borman, W.C. (Eds.), Personnel selection in organisations, 1st edn., pp. 71-98. San Francisco, CA: JosseyBass.

Bresnen, M. and Marshall, N. (2000) Partnering in construction: a critical review of issues, problems and dilemmas. Constr. Manage. Econ., 18(2), 229-237.

Cherns, A.B. and Bryant, D.T. (1984) Studying the client's role in construction management. Constr. Manage. Econ., 2(2), 177 - 184. 
Cheung, G.W. and Lau, R.S. (2008) Testing mediation and suppression effects of latent variables: bootstrapping with structural equation models. Organ. Res. Methods, 11(2), 296-325.

CIRC (2001) Construct for excellence, Hong Kong: Construction Industry Review Committee Courtney, R. and Winch, G.M. (2003) Re-engineering construction: the role of research and implementation. Build. Res. Inf., 31(2), 172.

Crowne, D.P. and Marlowe, D. (1960) A new scale for social desirability independent of psychopathology. J. Consult. Psychol., 24, 349-354.

Dainty, A., Bryman, A., Price, A., Greasley, K., Soetanto, R. and King, N. (2005) Project affinity: the role of emotional attachment in construction projects Constr. Manage. Econ., 23(3), 241-244.

Dainty, A.R.J., Cheng, M.-I. and Moore, D.R. (2005) Competency-based model for predicting construction project managers' performance. J. Manage. Eng., 21(1), 2-9.

Eisenberger, R., Huntington, R., Hutchison, S. and Sowa, D. (1986) Perceived organisational support. J. Appl. Psychol., 71(3), 500-507.

Fellows, R. (2006) Culture. In: Lowe, D. and Leiringer, R. (Eds.), Commercial management of projects: defining the discipline, pp. 40-70. Oxford: Blackwell Publishing.

Francis, V. (2010) A twenty year review of women's participation within the construction trade sector of the Australian construction industry. In, Construction, Building and Real Estate Research (COBRA) Conference, 2-3 September, Dauphine Université, Paris. RICS.

Fuller, J.B., Hester, K., Barnett, T., Beu, D., Frey, L. and Relyea, C. (2009) Extending the Group Engagement Model: an examination of the interactive effects of prestige, respect, and employee role Identity. J. Manage. Issues, 21(1), 119-139. 
Gaertner, S.L. and Dovidio, J.F. (2000) Reducing intergroup bias: the common ingroup identity model. Philadelphia, PA: Psychology Press.

Gold, M., Ed. (1999) The complete social scientist : a Kurt Lewin reader. 1st edn. Washington, DC: American Psychological Association.

Gregor, M., Ed. (1998) Kant: Groundwork of the metaphysics of morals. Cambridge: Cambridge University Press.

Hair, J.F., Black, W.C., Babin, B.J. and Anderson, R.E. (2010) Multivariate data analysis: a global perspective. 7th ed. Upper Saddle River, NJ: Pearson/Prentice Hall.

Hardy, C.L. and Van Vugt, M. (2006) Nice guys finish first: the competitive altruism hypothesis. Pers. Soc. Psychol. B., 32(10), 1402-1414.

Hofstede, G., Hofstede, G.J. and Minkov, M. (2010) Cultures and organizations: software of the mind. 3rd Edition ed. New York, NY: McGraw-Hill USA.

Hong Kong Census and Statistics Department (2011) Labour force characteristics. [Available online from http://www.censtatd.gov.hk/FileManager/EN/Content_1149/T04_16.xls ] Retrieved 8 October.

Kahn, K.B. (2005) Department status: an exploratory investigation of direct and indirect effects on product development performance. J. Prod. Innov. Manage., 22(6), 515-526. Kane, R. (1998) Dimensions of value and the aims of social inquiry. Am. Behave. Sci., 41(4), 578-597.

Katz, D. (1964) The motivational basis of organisational behaviour. Behav. Sci., 9(2), 131146. 
Katz, D. and Kahn, R.L. (1978) The social psychology of organisations. 2nd ed. New York, NY: Wiley

Katzenbach, J.R. (2003) Why pride matters more than money: the power of the world's greatest motivational force. New York: Crown Business

Katzenbach, J.R. and Smith, D.K. (1993) The wisdom of teams creating the highperformance organization. Boston, MA: Harvard Business School Press.

Khalil, E.L. (2000) Symbolic products: prestige, pride and identity goods. Theory and Decision, 49(1), 53-77.

Kumaraswamy, M.M., Rahman, M.M., Ling, F.Y.Y. and Phng, S.T. (2005) Reconstructing cultures for relational contracting. J. Constr. Eng. Manage., 131(10), 1065-1075.

Lawrence, P.R. and Lorsch, J.W. (1967) Organization and environment : managing differentiation and integration. Boston :: Division of Research, Graduate School of Business Administration, Harvard University.

Lingard, H. and Francis, V. (2005) Does work-family conflict mediate the relationship between job schedule demands and burnout in male construction professionals and managers? Constr. Manage. Econ., 23(7), 733-745.

Lingard, H.C., Francis, V. and Turner, M. (2010) Work-family enrichment in the Australian construction industry: implications for job design. Constr. Manage. Econ., 28(5), 467480.

Liu, A.M.M., Chiu, W.M. and Fellows, R. (2007) Enhancing commitment through work empowerment. Eng. Const. Arch. Manage., 14(6), 568 - 580. 
Liu, A.M.M., Fellows, R. and Tuuli, M.M. (2011) The role of corporate citizenship values in promoting corporate social performance: towards a conceptual model and a research agenda. Constr. Manage. Econ., 29(2), 173-183.

Lozano, L.M., García-Cueto, E. and Muñiz, J. (2008) Effect of the number of response categories on the reliability and validity of rating scales. Methodology, 4(2), 73-79.

Luhtanen, R. and Crocker, J. (1992) A collective self-esteem scale: self-evaluation of one's social identity. Pers. Soc. Psychol. B., 18(3), 302-318.

MacKinnon, D.P., Lockwood, C.M. and Williams, J. (2004) Confidence limits for the indirect effect: distribution of the product and resampling methods. Multivar. Behav. Res., 39(1), $99-128$.

Mael, F. and Ashforth, B.E. (1992) Alumni and their alma mater: a partial test of the reformulated model of organizational identification. J. Organ. Behave., 13(2), 103-123. Marrone, J.A. (2010) Team boundary spanning: a multilevel review of past research and proposals for the future. J. Manage., 36(4), 911-940.

Mascolo, M.F. and Fischer, K.W. (1995) Developmental transformations in appraisals for pride, shame, and guilt. In: Tangney, J.P. and Fischer, K.W. (Eds.), Self-conscious emotions: the psychology of shame, guilt, embarrassment, and pride, pp. 64-113. New York, NY: Guilford Press.

Mathieu, J., Maynard, M.T., Rapp, T. and Gilson, L. (2008) Team effectiveness 1997-2007: a review of recent advancements and a glimpse into the future. J. Manage., 34(3), 410476.

Mohammed, S., Ferzandi, L. and Hamilton, K. (2010) Metaphor no more: a 15-year review of the team mental model construct. J. Manage., 36(4), 876-910. 
Motowidlo, S.J. and Van Scotter, J.R. (1994) Evidence that task performance should be distinguished from contextual performance. J. Appl. Psychol., 79(4), 475-480.

Ness, K. (2010) The discourse of 'Respect for People' in UK construction. Constr. Manage. Econ., 28(5), 481-493.

Nicolini, D. (2002) In search of 'project chemistry'. Constr. Manage. Econ., 20(2), 167 - 177.

O'Reilly, C.I. and Chatman, J. (1986) Organisational commitment and psychological attachment: the effects of compliance, identification, and internalization on prosocial behaviour. J. Appl. Psychol., 71(3), 492-499.

Orr, J.M., Sackett, P.R. and Mercer, M. (1989) The role of prescribed and nonprescribed behaviours in estimating the dollar value of performance. J. Appl. Psychol., 74(1), 3440.

Paulhus, D.L., Robins, R.W., Trzesniewski, K.H. and Tracy, J.L. (2004) Two replicable suppressor situations in personality research. Multivar. Behav. Res., 39(2), 303 - 328.

Pesämaa, O., Eriksson, P.E. and Hair, J.F. (2009) Validating a model of cooperative procurement in the construction industry. Int. J. Proj. Manage., 27(6), 552-559. Pettigrew, T.F. (1998) Intergroup contact theory. Annu. Rev. Psychol., 69, 65-85. Phua, F.T.T. (2004) The antecedents of co-operative behaviour among project team members: an alternative perspective on an old issue. Constr. Manage. Econ., 22(10), 1033-1045.

Pinto, M.B. and Pinto, J.K. (1990) Project team communication and cross-functional cooperation in new program development. J. Prod. Innov. Manage., 7(3), 200-212. 
Podsakoff, P.M., Ahearne, M. and MacKenzie, S.B. (1997) Organisational citizenship behaviour and the quantity and quality of work group performance. J. Appl. Psychol., $82(2), 262-270$.

Preacher, K.J. and Hayes, A.F. (2008) Asymptotic and resampling strategies for assessing and comparing indirect effects in multiple mediator models. Behav. Res. Methods, 40(3), 879-891.

Respect for People Working Group (2004) Respect for people: a framework for action, Constructing Excellence.

Roland, C.E. and Foxx, R.M. (2003) Self-respect: a neglected concept. Philos. Psychol., $16(2), 247-288$.

Rowlinson, S. and Cheung, Y.K.F. (2008) Stakeholder management through empowerment: modelling project success. Constr. Manage. Econ., 26(6), 611 - 623.

Sackett, P.R. (2002) The structure of counterproductive work behaviours: dimensionality and relationships with facets of job performance. Int. J. Select. Assess., 10(1\&2), 5-11.

Shrout, P.E. and Bolger, N. (2002) Mediation in experimental and nonexperimental studies: new procedures and recommendations. Psychol. methods, 7(4), 422-445.

Sirota, D., Mischkind, L.A. and Meltzer, M.I. (2005) The enthusiastic employee. Upper Saddle River, NJ: Wharton School Publishing.

Smith, C.A., Organ, D. and Near, J. (1983) Organisational citizenship behaviour: its nature and antecedents. J. Appl. Psychol., 68(4), 653-663.

Stone-Romero, E.F., Alvarez, K. and Thompson, L.F. (2009) The construct validity of conceptual and operational definitions of contextual performance and related constructs. HRM Rev., 19(2), 104-116. 
Strahan, R. and Gerbasi, K.C. (1972) Short, homogeneous versions of the Marlowe-Crowne social desirability scale J. Clin. Psychol., 28, 191-193.

Toor, S.-U.-R. and Ofori, G. (2010) Positive psychological capital as a source of sustainable competitive advantage for organizations. J. Constr. Eng. Manage., 136(3), 341-352.

Tracy, J.L. and Robins, R.W. (2004) Putting the self into self-conscious emotions: a theoretical model. Psychol. Inq., 15(2), 103-125.

Tuuli, M.M. and Rowlinson, S. (2009) Empowerment in project teams: a multilevel examination of the job performance implications. Constr. Manage. Econ., 27(5), 473 498.

Tyler, T.R. and Blader, S.L. (2000) Cooperation in groups: procedural justice, social identity and behavioural engagement. Philadelphia: Psychology Press.

Tyler, T.R. and Blader, S.L. (2001) Identity and cooperative behaviour in groups. Group Process Interg., 4(3), 207-226.

Tyler, T.R. and Blader, S.L. (2003) The group engagement model: procedural justice, social identity, and cooperative behaviour. Pers. Soc. Psychol. Rev., 7(4), 349-361.

Tzelgov, J. and Henik, A. (1991) Suppression situations in psychological research: definitions, implications, and applications. Psychol. Bull., 109(3), 524-536.

Williams, L.A. and DeSteno, D. (2008) Pride and perseverance: the motivational role of pride. J. Pers. Soc. Psychol., 94(6), 1007-1017.

Williams, L.A. and DeSteno, D. (2009) Pride: adaptive social emotion or seventh sin? Psychol. Sci., 20(3), 284-288. 
Williams, L.J. and Anderson, S.E. (1991) Job satisfaction and organizational commitment as predictors of organizational citizenship and in-role behaviours. J. Manage., 17(3), 601617.

Winter, M., Smith, C., Morris, P. and Cicmil, S. (2006) Directions for future research in project management: the main findings of a UK government-funded research network. Int. J. Proj. Manage., 24(8), 638-649.

Worrall, L., Harris, K., Stewart, R., Thomas, A. and McDermott, P. (2010) Barriers to women in the UK construction industry. Eng. Const. Arch. Manage., 17(3), 268-281. Zhao, X., Lynch Jr., John G. and Chen, Q. (2010) Reconsidering Baron and Kenny: myths and truths about mediation analysis. J. Consum. Res., 37(2), 197-206. 


\section{Appendix: Scale items and factor loadings}

\begin{tabular}{|c|c|c|}
\hline Variable & Items & $\begin{array}{l}\text { Standardized } \\
\text { factor loading }^{a}\end{array}$ \\
\hline Cooperation & (anchors: 1 = "never" to 5 = "very often") & \\
\hline \multicolumn{3}{|l|}{$\%$ Variance explained $=69.37$} \\
\hline In-role (5 items) & I fulfil the responsibilities specified in my job description & .83 \\
\hline Cronbach's alpha $=.89$ & I perform the tasks that are expected as part of my job & .86 \\
\hline \multirow[t]{3}{*}{ Min. item-total corr. $=.64$} & I meet the performance expectations for my job role & .81 \\
\hline & I adequately complete my required work tasks & .78 \\
\hline & I exert my full effort when getting my job done & .73 \\
\hline Extra-role (4 items) & I volunteer to do things that are not required in order to help & .60 \\
\hline Cronbach's alpha & my workgroup & \\
\hline \multirow[t]{3}{*}{ Min. item-total corr. $=.57$} & I make innovative suggestions to help improve my work setting & .71 \\
\hline & I volunteer to help others when they have heavy workloads & .81 \\
\hline & I lend a helping hand to others at work & .78 \\
\hline Compliance (3 items) & I comply with work related rules and regulations & .86 \\
\hline Cronbach's alpha $=.88$ & I follow the policies established by my supervisor & .86 \\
\hline Min. item-total corr. $=.70$ & I carefully try to carry out the instructions of my supervisor & .73 \\
\hline Deference (3 items) & I willingly follow my project organisation's policies & .69 \\
\hline \multirow[t]{2}{*}{$\begin{array}{l}\text { Cronbach's alpha }=.83 \\
\text { Min. item-total corr. }=.64\end{array}$} & $\begin{array}{l}\text { I do what my supervisor expects of me, even when I do not } \\
\text { think it is important }\end{array}$ & .85 \\
\hline & I willingly accept the decisions made by my supervisor & .87 \\
\hline Self-respect (4 items) & (anchors: 1 = "strongly disagree" to 5 = "strongly agree") & \\
\hline$\%$ Variance explained $=55.91$ & I am an important member of my workgroup & .67 \\
\hline Cronbach's alpha $=.73$ & I feel I don't have much to offer my workgroup (R) & .83 \\
\hline \multirow[t]{2}{*}{ Min. item-total corr. $=.45$} & I am a cooperative participant in my workgroup & .73 \\
\hline & I often feel I'm a useless member of my workgroup (R) & .75 \\
\hline Pride (5 items) & (anchors: 1 = "strongly disagree" to 5 = "strongly agree") & \\
\hline$\%$ Variance explained $=63.29$ & I would recommend to a close friend that they work where I do & .72 \\
\hline Cronbach's alpha $=.85$ & I agree with what my project organisation stands for & .78 \\
\hline \multirow[t]{3}{*}{ Min. item-total corr. $=.58$} & I find that my values and the values where I work are similar & .81 \\
\hline & I feel proud to be working where I am & .86 \\
\hline & I 'talk up' where I work to my friends as a good place to work & .81 \\
\hline Pay satisfaction ( 2 items) & (anchors: 1 = "strongly disagree" to 5 = "strongly agree") & \\
\hline$\%$ Variance explained $=90.28$ & Overall, I receive excellent pay and benefits where I work & .95 \\
\hline Cronbach's alpha $=.89$ & I am satisfied with my pay & .95 \\
\hline Min. item-total corr. & & \\
\hline
\end{tabular}

Notes:

${ }^{\mathrm{a}}$ For all variables, KMO MSA $\geq .50$ and Bartlett's test of sphericity is significant at $p<.001$.

$\mathrm{R}$, reverse-scored to create a scale. 


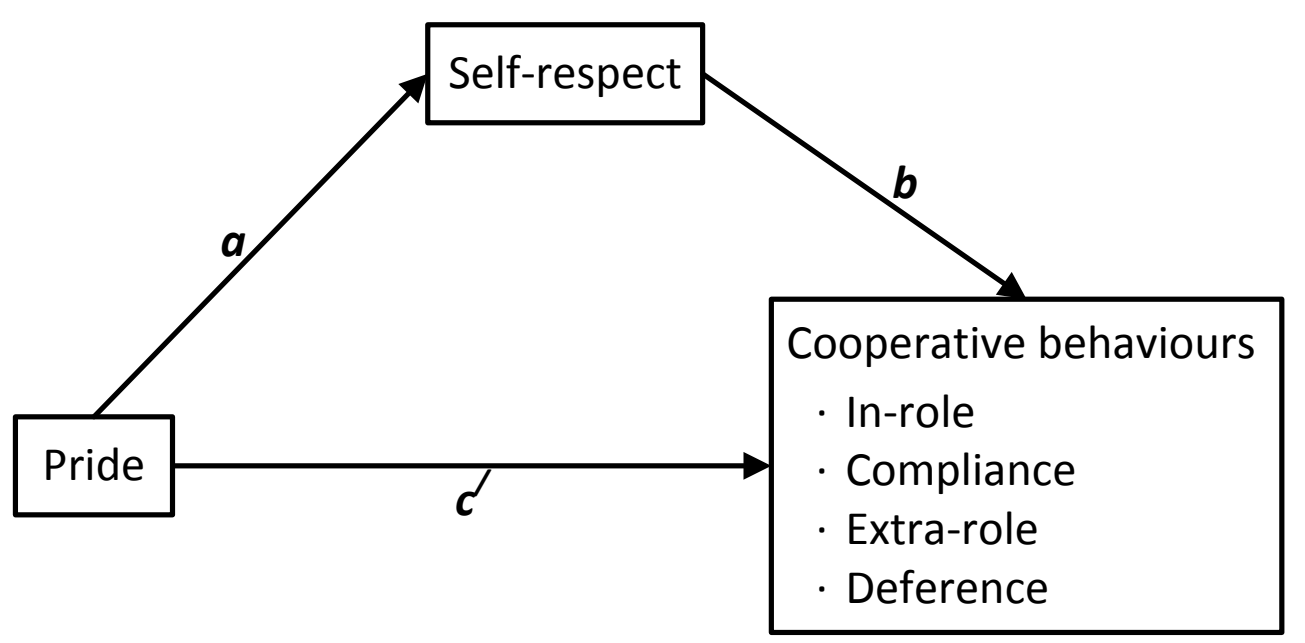

Figure 1: Model of the relationships between pride, self-respect and cooperation 
Table 1. Descriptive statistics and correlations among study variables

\begin{tabular}{lccccccccccccc}
\hline Variables & $M$ & $S D$ & 1 & 2 & 3 & 4 & 5 & 6 & 7 & 8 & 9 & 10 & 11 \\
\hline 1. Ethnicity & .72 & .45 & - & & & & & & & & & & \\
2. Age & .67 & .47 & -.10 & - & & & & & & & & & \\
3. Gender & .04 & .19 & .03 & -.19 & - & & & & & & & & \\
4. Education & .55 & .50 & .01 & .04 & .02 & - & & & & & & & \\
5. Pay satisfaction & 3.00 & .90 & -.03 & .23 & .09 & .09 & .89 & & & & & & \\
6. Pride & 3.31 & .69 & .05 & .10 & -.01 & .18 & .45 & .85 & & & & & \\
7. Self-respect & 4.09 & .61 & -.10 & .18 & -.06 & .09 & .17 & .39 & .73 & & & & \\
8. In-role & 4.10 & .54 & .03 & .00 & -.02 & .01 & .16 & .24 & .35 & .89 & & & \\
9. Compliance & 4.05 & .61 & .20 & .01 & .03 & .14 & .13 & .23 & .25 & .41 & .88 & & \\
10. Extra-role & 3.67 & .60 & -.06 & .04 & -.07 & -.02 & .20 & .31 & .34 & .51 & .32 & .78 & \\
11. Deference & 3.73 & .65 & .17 & -.04 & .04 & .13 & .11 & .19 & .20 & .27 & .58 & .25 & .83 \\
\hline
\end{tabular}

Notes. $N=140$. All correlations $>.16$ have $p<.05$.

Entries below the diagonal are Pearson's product-moment correlations. Diagonal entries, where available, are the Cronbach's alphas for each scale.

Dummy variables were coded as follows: ethnicity, $0=$ non-Chinese and $1=$ Chinese; age, $0 \leq 40$ years and $1>$ 40 years; gender, $0=$ male and $1=$ female; educational attainment, $0=$ undergraduate degree or below and $1=$ postgraduate education.

Summated scale items were scored on 5-point Likert scales with high numbers indicating more of the construct. 
Table 2. Results of regression analyses

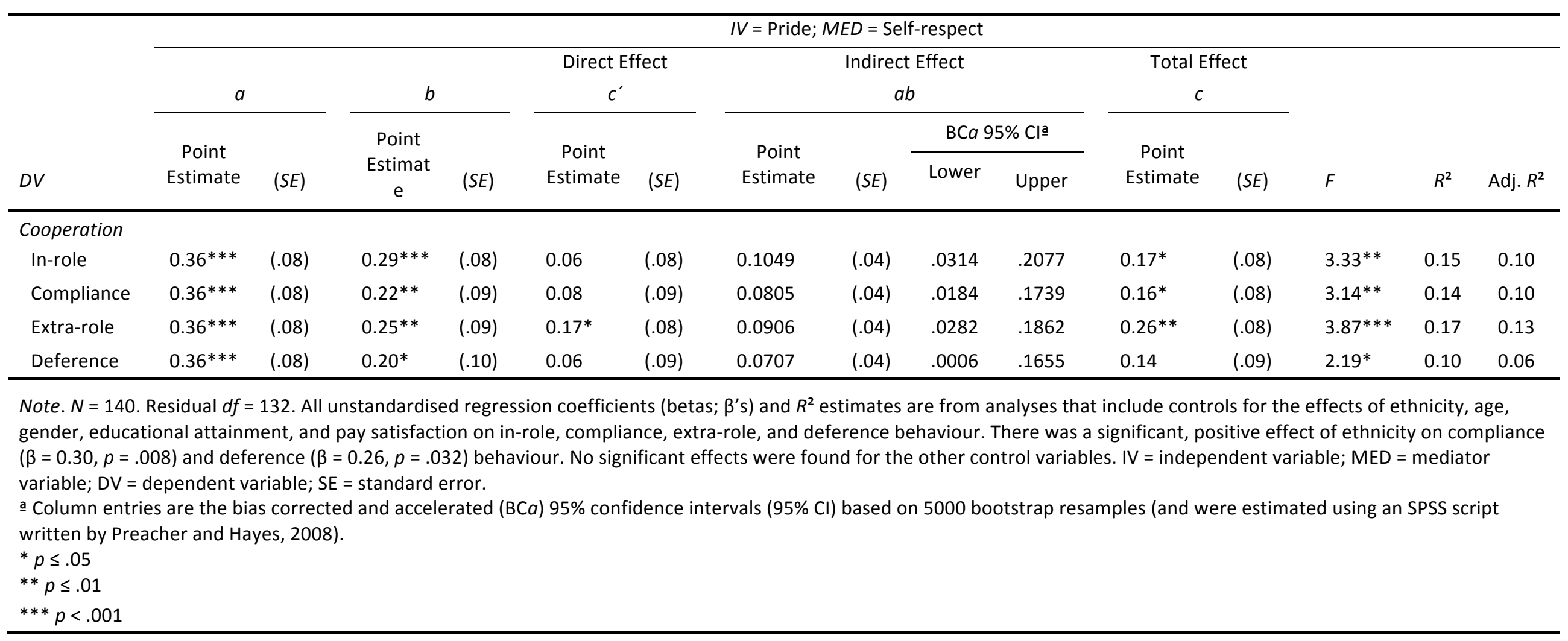

